\title{
Eyeless in Guantanamo: Vanishing Horizons in Kamila Shamsie's Burnt Shadows
}

Pascal Zinck

\section{(2) OpenEdition \\ 1 Journals}

Electronic version

URL: https://journals.openedition.org/ces/8302

DOI: $10.4000 /$ ces.8302

ISSN: 2534-6695

Publisher

SEPC (Société d'études des pays du Commonwealth)

\section{Printed version}

Date of publication: 1 September 2010

Number of pages: $45-54$

ISSN: 2270-0633

\section{Electronic reference}

Pascal Zinck, "Eyeless in Guantanamo: Vanishing Horizons in Kamila Shamsie's Burnt Shadows", Commonwealth Essays and Studies [Online], 33.1 | 2010, Online since 11 December 2021, connection on 20 January 2022. URL: http://journals.openedition.org/ces/8302 ; DOI: https://doi.org/10.4000/ces. 8302

\section{cc) (†)}

Commonwealth Essays and Studies is licensed under a Licence Creative Commons Attribution - Pas d'Utilisation Commerciale - Pas de Modification 4.0 International. 


\section{Eyeless in Guantanamo: Vanishing Horizons in Kamila Shamsie's Burnt Shadows}

Any call to the horizon implies setting out from one's home, territory or country to embark on a journey towards the unknown. Such a trajectory which informs narratives of migration and exile is a defining trait of diasporic studies. The perception of this trajectory has changed over the years with the contestation of Christian teleology, imperialism and global capitalism. After two World Wars, the horrific events of the Shoah and the nuclear holocaust, after the dislocation of traditional societies and mass-migrations of newlyindentured labour, the horizon has become a locus of fracture, trauma and division. Focusing on the politically charged horizons of Kamila Shamsie's Burnt Shadows, from Nagasaki to pre and post-Partition India, Pakistan, Afghanistan and Guantanamo, the present paper examines fragmentation and the problem of identity in the context of the narrator's fugitive condition.

Tamila Shamsie's Burnt Shadows (2009) reflects the tensions and ambiguities of all diasporic fictional discourse as narratives of

1 dislocation and relocation, erasure, deferment and nostalgia (Nelson 1992). The end of the Cold War has coincided with the rise of US hegemony - a combination of unilateralism and cultural imperialism (Tomlinson 1991). Influenced by Gramsci, theorists like Edward Said, Immanuel Wallerstein, Noam Chomsky, Michael Hardt and Toni Negri have launched a critique against globalisation and the Americanisation of culture. ${ }^{1}$ This process of homogenisation which arguably undermines local and minority cultures can produce acculturation (Robertson 1995), resistance - from theoretical (the "Writing Back" paradigm expounded by Spivak, Rushdie and Ashcroft amongst others) to outright military confrontation. ${ }^{2}$ Shamsie examines these tensions, along with the central questions of homeland and identity that have come into sharper focus in the context of 9/11 and the "War on Terror" rhetoric. Like Mohsin Hamid's Reluctant Fundamentalist, Burnt Shadows offers an insight into Islamic terrorism, not perceived as merely a response to Islamophobia, but as a reaction to and a by-product of cultural globalisation. While Hamid uses fictional as well as holographic techniques to deconstruct and reconstruct the figure of the terrorist, Shamsie deterritorialises terror by decentering the 9/11 attacks and placing them in a broader historical perspective.

Framed by two major, albeit disproportionate, collisions - the WWII nuclear holocaust and 9/11, the novel chronicles the tribulations and traumas of two

1 See Said 1993, Wallerstein 2001, Chomsky 2003, Hardt and Negri 2001.

2 See Spivak 1985 and 1994, Rushdie 1982 and 1991, Ashcroft et al. 2002. 
families, the Tanaka-Ashrafs and the Weiss-Burtons over three generations. It consists of a series of four interlinked sections spanning a period of sixty years, all of which are marked by rupture, mourning and the loss of home or the homeland. In the opening section entitled "The Yet Unknowing World: Nagasaki, 9 August 1945," the main protagonist, Hiroko Tanaka, survives the inferno, unlike Konrad Weiss, her German fiancé trapped in "the Valley of Death," the Conradian equivalent to "the heart of darkness" (BS 27, 76-77). ${ }^{3}$ Hiroko mourns Konrad by escaping to India to join his sister Elizabeth (née Ilse Weiss) and her husband James Burton. It is highly significant that all subsequent migrations should relate to this initial horizon shift. Hiroko, for one, has imprinted on her seared flesh the kimono cranes which symbolize both her hibakusha condition and flight. ${ }^{4}$ The second section entitled "Veiled Birds: Delhi, 1947" introduces the second family, the Burtons, as their marriage disintegrates in the twilight of the British Raj. They leave "Bungle-Oh," their colonial enclave in Delhi, for the mist-shrouded Himalayan hill station of Mussoorie where they contemplate their separate postcolonial future. Their son, Henry Burton (later Harry) is despatched to a boarding school in England where he will grow into a Kipling-like figure mourning a lost Indian childhood. Conversely, Hiroko is drawn to Sajjad Ali Ashraf, an Indian Muslim and legal apprentice of James Burton. ${ }^{5}$ In a scene reminiscent of $A$ Passage to India, Saijad is evicted for allegedly sexually abusing the young Japanese refugee. Eventually, the couple marries despite the Burtons' initial misgivings. Because of the Partition riots, Hiroko and Sajjad honeymoon in a decrepit Turkish yali. On their return, they are denied entry to their own country and are compelled to relocate in Pakistan.

The third section called "Part-Angel Warriors: Pakistan, 1982-3" unfolds in Karachi, or more precisely, in the Muhajir sprawl of Nazimabad where the Ashrafs have resettled and raised a son, Raza Konrad Ashraf. ${ }^{6}$ Raza who cannot understand his mother's sense of being "at home in the idea of foreignness," (141) is torn between his fascination for American icons and Afghan mujahedeen. Caught between the growing pressures of consumerism and Islamic fundamentalism, the

3 The paginations for all subsequent quotations from Burnt Shadows will be given directly between parentheses in the body of the text.

4 Hibakusha is the Japanese term designating the victims of the nuclear bombings of Hiroshima and Nagasaki. It is often used to mark them as pariahs as in Ame Kuroi. Hiroko attributes her miscarriage to the A-bomb radiation poisoning.

5 Sajjad - whose main occupation is to alleviate his colonial master's ennui, and serve as a foil to his matrimonial breakdown - is a pitiful avatar of the Maharajahs reduced to humouring their victors. The Burtons are blissfully unaware of the young man's pedigree as both his name Ashraf and first name Shajjad - Shah (Lord) and zad (son) - denote aristocratic parentage.

6 The term Muhajir or Mohajir refers to the Urdu speaking Muslim people who migrated to Pakistan from India in the aftermath of partition. The overwhelming majority settled in Karachi and faced overt discrimination. 
novel alternates between Karachi and its Afghan slums of mud, jute and sackcloth in Sohrab Goth, as well as the vanishing lines on the Afghan/Pakistan border. The other divisive border space of Kashmir Point is briefly mentioned (BS 148). For all his linguistic prowess, Raza Konrad Ashraf suffers from confusion and alienation. His self-perception as a "bombed-marked mongrel" (191 e.g.) duplicates his academic failure (his Islamic studies paper) and prompts him to reinvent himself under the camouflage of Raza Hazara, the Afghan mujahid. As the web of deceit is exposed, his father is mistakenly shot dead as an undercover ISI agent. The title of the fourth and final section, "The Speed Necessary to Replace Loss: New York, Afghanistan, 2001-2," is borrowed from Michael Ondaatje's The English Patient, and resonates with the spy fiction of John Le Carré. The sanctuary that Ilse Weiss offers Hiroko, and Hiroko in turn offers Ilse's granddaughter Kim ${ }^{8}$ is short-lived as planes crash into the WTC Twin Towers. Their two sons, Harry Burton and Raza Ashraf, find themselves embroiled in America's "proxy wars" as private mercenaries for the CIA in Afghanistan. An operation goes quite wrong, and Harry is killed by a Taliban double agent. Accused of helping the insurgents, Raza goes to ground, and plans to be smuggled back to the US.

The common denominator to all the novel's horizon shifts is the collision between the aspirations of human agency and the homogenisation of culture imposed by geopolitics. A closer inspection of the way these ruptures are interrelated provides a clue to Shamsie's critique of US-centred globalisation. It is highly significant that these shifts should occur in Nagasaki, Karachi and New York, three ports epitomising tolerance and multiculturalism. These windows to the world are shattered as a result of US imperialism. It is no small coincidence either that the Bosporus should provide a safe haven during the riots glossed over by the former colonial masters as the "Partition nonsense" (BS 122), as the strait physically marks the boundary between the East and the West. Nagasaki, first described as "a world of enchantment," a cosmopolitan city with "Europeans and Japanese mixing uncomplicatedly" has been distorted into a functional form (6). Hiroko who, as a language translator, provides the keys to the novel's ciphers, is watched by the military police for anti-state activity, and is shunned by the Neighbourhood Association - her father is branded an artist traitor. She mistakenly believes that the new nuclear bomb will spare the predominantly Christian city. Contrary to Kazuo Ishiguro's Etsuko Sheringham, who accepts her defeats with resignation and amnesia (Ishiguro 1982), Shamsie's narrator refuses to be defined or marginalised as a hibakusha victim. Sajjad equally pines for the

7 Hana envies Kirpal Singh's ability to move "at a speed that allowed him to replace loss." (Ondaatje 272) There are further parallels between the two novels, particularly the young Indian's sudden decision to turn his back on the battlefields of Europe towards the end of WWII, as he hears about Hiroshima and Nagasaki.

8 The novel acknowledges the postcolonial reference to Kipling (BS 185). 
loss of pre-Partition hybridity, "the essential Dilliness" of his moholla, even if it means idealising ethnic and religious harmony in colonial India:

"They said I chose to leave." He said the words slowly, carefully, as though they were a foreign language whose meaning he was trying to grasp. "They said I'm one of the Muslims who chose to leave India. It can't be unchosen. [T] hey said I can't go back to Dilli. I can't go back home." (BS 125, see also 134, 161)

Sajjad's grief echoes Mirza Ghalib's ghazals and the nostalgia for "Rupnagar" mourned in Intizar Husain's nostalgic Basti. His "wilderness of loss" is all the more inconsolable as he had earlier challenged the British coloniser's unwillingness to acculturate:

Why have the English remained so English? Throughout Indias history conquerors have come from elsewhere, and all of them - Turk, Arab, Hun, Mongol, Persian - have become Indian. If - when this Pakistan happens, those Muslims who leave Delhi and Lucknow and Hyderabad to go there, they will be leaving their homes. But when the English leave, they'll be going home. (BS 82)

In Delhi, Hiroko had insisted on learning Urdu to build her resilience to trauma. Thus she was better able to cope in the post-Partition refugee camps. She rapidly embraced Karachi as a vibrant hub and a multicultural mosaic: "People here are from every nation within Pakistan. Baloch, Pathan, Sindhi, Hindu, Sikh even. Everyone." (160) Further evidence of her multicultural self can be found in her (cross) dressing as well as in her participation in the Japanese cultural soirées at Jimmy's Coffee Shop. Shamsie examines the underpinnings of cultural acculturation in England, as opposed to more recent nation-states, including the United States, with their mass migrations. On leaving India, Henry Burton finds himself ostracised like Christopher Banks (Ishiguro 2000). He becomes a scapegoat under the nickname "Maharaja Fritz," until he can redeem himself through his cricketing skills (170). In New York, by contrast, the perception of his foreignness is short-lived, as he realises that the mystique of caste no longer operates. With money becoming the prevailing social determiner, Henry Burton can reinvent himself as Harry and proselytise: "In America, everyone can be American. That's the beauty of the place" (185, see also 170). ${ }^{9}$ Shamsie's protagonist can enjoy the luxury of belonging, precisely because he is not perceived as a Third World subaltern. One feels tempted to level the same kind of charge against Shamsie as Benita Parry does against Homi K. Bhabha's arguably reductive cosmopolitan and bourgeois representations of migrations:

Those infatuated by the liberatory effects of dispersion do not address the material and existential conditions of the relocated communities which include economic migrants, undocumented immigrants, refugees, asylum seekers and victims of

9 Belying his mantra, Harry later dangles before Raza the talisman of an entry to an American college, only to cancel the magic spell, thus driving the disillusioned young Pakistani into the clutches of the mujahedeen. 
ethnic cleansing, and whose mobility, far from being an elective ethical practice, is coerced. (Parry 100)

Yet the criticism of privileging an elite transnational migrant class is deflated with the introduction of a Pakistani-born yellow cab driver. Admittedly, cabbie Omar of Gujranwala may sound over-articulate when displaying his newly acquired American citizenship, and profusely welcoming Hiroko "home" (288). However, his working class solidarity with fellow Indian cab drivers for better work conditions is no more contrived than the vitriolic anti-Semitic ranting of the Muslim cabbie in Fury (Rushdie 65). Hiroko may equally lay herself open to the critique of elitism as she tunes in to conversations in Urdu, English, Japanese and German, and as she embraces the fluidity and mobility of Manhattan in Mary Poppins-like fashion: "she felt she had been waiting all her life to arrive here" (289). Yet her hibakusha womanhood, independence of mind, and multicultural ethics lead her to reach out to those who do not have the privilege "to be Ellis Islanded" (Rushdie 51). As a result, Hiroko responds uniquely to $9 / 11$ and the ubiquitous climate of fear. She first volunteers to donate her blood, but as she confronts the sudden manifestations of patriotism, she is reminded of similar justifications for the dropping of nuclear bombs on Nagasaki. For her, the flattening of the Urakami cathedral and the World Trade Centre are two inexcusable tragedies caused by American hubris.

Both Kim Burton and Hiroko witness the fires smouldering at Ground Zero. Yet, both respond quite differently to the "War on Terror" rhetoric and its attendant Islamophobia. Unlike multicultural Hiroko, Kim develops a paranoid sense of patriotism together with a deep mistrust of anything un-American. She eyes an Italian removal man suspiciously, and confronts him as a Muslim. Long erased is her sense of wonderment at an armadillo-like mosque on the outskirts of Islamabad. A similar anti-Islamic propaganda was deployed in Shamsie's earlier novel, Broken Verses:

"And then?"

"And then the Towers fell."

"And you stopped being an individual and started being an entire religion." (Shamsie 2005, 45)

Hiroko, on the other hand, has no hesitation in befriending an Afghan illegal immigrant, first at the American Library, where the two expatriates muse over sepia photographs of Kandahar orchards, then at her home, to Kim's dismay (BS311-4). Contrary to Omar, the cab driver, the acculturation paradigm does not work for Abdullah Durrani, Raza's former boyhood friend and mujahid copycat. The young Afghan who has left behind a wife and son, also named Raza, for the American Eldorado, is on the run from the FBI. Aware of the implications of the Patriot Act and of the prevailing paranoia against Muslims, Raza orchestrates his former friend's repatriation back to Afghanistan from Canada. Hiroko readily offers her assistance as a mother, a refugee and a witness of the lethal power of the 
border spaces (Magris 76). At the same time, her support can also be interpreted as a kind of atonement or compensation. Indeed, when growing up in Pakistan, her son's perception of his foreignness and linguistic proficiency further exacerbated his sense of disconnection and feelings of unbelonging to such an extent that he either saw himself as a hibakusha "mongrel" or "UnPakistani" (189 e.g.).

Unbeknown to Hiroko, Abdullah's clandestine return to Afghanistan depends on the success of another covert operation - the smuggling of Raza back to the US via Canada. This inverted journey emphasises the similarities between the two friends, while highlighting the interconnectedness of the geopolitical situation, and the ensuing Islamophobia and demonisation of the US. As a result of his involvement with the CIA, under the dubious tutelage of Harry (aka Warbucks), the theme of dislocation and the issues of terrorism and asylum are given an ironic twist. Accused of being complicit in Harry Burton's killing by Taliban infiltrators, Raza Ashraf must ditch his US green card and ID. He must also renounce his lifestyle as a high flier to embrace the plight of Third World trafficking victims lured to America's Eldorado. This "initiatic" odyssey - a variation on "the slave route" prophetically evoked (160) - takes him to Kandahar under the disguise of a burqa, across the Desert of Death, the Afghan border with Iran, in a ramshackle pickup where he is smothered by cabbages, across the Gulf of Oman to Muscat under the planks of a coffin-like boat (335-6). The chaotic journey has Celinean undertones, as Raza conjures up visions of mass graves in Kosovo. Finally, the last leg of his journey to Montreal has Raza travelling in a gorilla suit in the company of exotic or endangered species supplied for the well-being of Saudi expatriates. The irony of the prospective exchange between Raza and Abdullah should be noted: it seems far easier to be smuggled into the US than to attempt to exit clandestinely. The novel's greater irony is that Raza can only escape the battlefield under the guise of "the subalterns," on whose behalf the war is being waged.

Shamsie's comparison of the victims of ethnic warfare and Third World economic slaves draws from Spivak's theory of the subaltern and Mbembe's concept of "disposable bodies" available for the West to consume (Mbembe 11-40) - the term "expendable" is indeed used by Hiroko (BS 362). The increasing US reliance on mercenaries and TCNs to fight its controversial war further illustrates Mbembe's concepts of "necropolitics" and "necropower." One CIA commander dismisses Raza as "one of the grunts who know their positions can be filled by a million other desperate rats." (304) In its global war on terror - GWOT - the US uses free market ideology to privatise war, generate profits through unscrupulous labour practices, commit atrocities by proxy, and outsource death to foreign others, mostly Third World paupers. Thus, the hiring of foreign have-nots renders many of the deaths required for the war effort in Afghanistan invisible (Singer 2003, Avant 2005).

More significantly, the reason for the failure of the exchange between the two illegals should be analysed. Kim's demonisation of Muslims leads her to construe the Afghan refugee as a potential terrorist, an oversimplification to which 
Abdullah takes offence. As Abdullah says in exasperation, "everyone just wants to tell you what they know about Islam, how they know so much more than you do, what do you know, you've just been a Muslim all your life." (352) Kim's sudden aversion for Muslims resonates with her father's conspiracy theories about the Oklahoma bombings and a jihadi connection. For all his hybridisation and war camouflage as Lala Buksh, Harry Burton sees the world in Manichean Cold War terms, and is, in the end, as much an epitome of America's predatory greed as Max Ophuls (Rushdie 2005). ${ }^{10}$ The reader is reminded of a similar stigmatisation operating in Mohsin Hamid's The Reluctant Fundamentalist or in Uzma Aslam Khan's Trespassing. As a result, Kim foils the smuggling operation by tipping off the Canadian police. Hiroko's son is extradited and deported to Guantanamo. The young American's contribution to the crusade against terror resonates with McCarthyism:

We are the land of liberty, but today we hear voices - in the government, in the press, in the population at large - that we have accorded too much liberty, especially to non-citizens, and that "terrorists" have taken advantage of our liberty. Therefore it is said the privileges of liberty must give way to procedures that meet our requirements for security. (Wallerstein 1991)

Shamsie's use of the spy genre and her reworking of the Great Game (BS 185) allow her to engage in a critique of American imperialism masquerading as human rights ethics. Raza sees through Harry Burton's camouflage: "How long ago was it that you decided to justify your life by transforming responsibility into a disease." (286) Harry himself is aware of Uncle Sam's double standards, and the false assumptions they make that the end can ever justify any collateral damage:

"What would you do if it was effective?" Harry said thoughtfully.

"Almost nothing. Children are out of bounds, rape is out of bounds, but otherwise... what works, works. When I'm dead, Raza, and my daughter asks what kind of man her father really was, don't tell her I said that." (BS 284)

The novel draws on Chomsky's and Badiou's critique of US hegemony. The father of modern linguistics denounces America's post cold war unilateralism and manipulation of terror for propaganda purposes (Chomsky 2003). According to Alain Badiou, the "axis of evil" rhetoric serves as a smokescreen for geopolitical gains: "the colossal American army exerts terrorist blackmail on a global scale." (Badiou 2001/02) Chomsky and Badiou also argue that the US administration operates double standards. It champions the cause of human rights, liberating women from the yoke of a fundamentalist patriarchy in Afghanistan while entrusting its war to mercenaries as well as minimising its responsibility in creating the Taliban after instrumentalising the mujahedeen against the Soviets.

10 In the same way, Raza becomes suspect and he is subsequently detained after he is seen praying outside his humvee. Raza is a victim of racial stereotyping just as his father, Saijad, had been at the hands of the Burtons. 
Why are five thousand American deaths considered a cause for war, while five hundred thousand dead in Rwanda and a projected ten million dead from AIDS in Africa do not, in our opinion, merit outrage? Why is the bombardment of civilians in the US Evil, while the bombardment of Baghdad or Belgrade today, or that of Hanoi or Panama in the past, is Good? (Badiou 2001/2002)

Like them, Shamsie exposes the fallacy of "liberation" and "democratisation" as well as the self-delusion that America's "Others are less free than we are. The Statue of Liberty stretches out its hand to all those huddled masses yearning to breathe free." (Wallerstein 2001) Burnt Shadows also raises the issue of "Jihad versus MacWorld” (Barber 1996). The novel partly correlates Raza's estrangement and his Afghan odyssey to Pakistan's growth and conversion to a mass market economy, in response to the rise of materialism associated with the US or the Gulf Emirates. Conversely, as Wallerstein notes, "the image of the less-ness of the rest of the world is profoundly ingrained in the American psyche." (Wallerstein, 2001) American consumerism and propaganda is so effective that even recent immigrants like the Pakistani taxi driver espouse this stereotype.

The US military might provide a further source of resentment. Abdullah's older brother, Ismail declares that by opting for a military escalation, firing drones indiscriminately, propping up feudal overlords, and turning a blind eye to the extortion of their private militias, the US has destabilised Afghanistan and driven its helpless farmers turned refugees to the fold of the Taliban:

I told you. I'm a farmer. I want to plant crops and harvest them. Do you understand? I need peace for this. I need security. In exchange for that, there is much that I'll give up. [...] To watch my sons measure hand-span against a pomegranate, not a grenade. But the Taliban - they don't know Sufis or orchards. They grew up in refugee camps, with no memory of this land, no attachment to anything except the idea of fighting infidels and heretics. So when they came, they brought laws different to the laws I grew up with. So what? (BS 320)

The farmer's passive acceptance of the Taliban echoes the deterritorialisation and deprivation of the Afghan refugees in the slums of Karachi (195-199). Hence the children's fascination for the AK-47s and their elder siblings' readiness to embrace radical Wahabism.

Initially, this essay juxtaposed two traumatic world events, the nuclear bombing of Nagasaki and 9/11. Indeed the flattening of Urakami cathedral heralds the collapse of the twin towers. However, the novel unsettles this chronological order by opening with a scene based on Guantanamo. The purpose of the prologue is twofold. First, the reader has to deconstruct the events and fathom the reasons why Raza "comes home" to Guantanamo almost literally, and by way of a complex exfiltration process. Secondly, by flagging Guantanamo as her starting point, Kamila Shamsie challenges Pax Americana, symbolised by the figure of liberty draped in red, white, and blue, which superseded the British Imperial order and advanced US hegemony in the twilight of the Cold War. The same 
Realpolitik accounts for Hiroshima/Nagasaki and 9/11, the "Green" peril being a continuation of the "Yellow" peril - Islamikaze emulating WWII kamikaze - or the anti-communist paranoia. Contrary to earlier diasporic fiction celebrating resilience, resourcefulness, acculturation or hybridity (Henry Roth, Saul Bellow, Bernard Malamud, Edwin O’Connor, John O’Hara, John Fante, Chang-rae Lee, Bharati Mukherjee...), more recent diasporic works focus on the failure of relocation and the need to return to one's homeland (Anita Rau Badami, Kiran Desai, Mohsin Hamid, Uzma Aslam Khan...). Clearly with its indictment of the post 9/11 discourse which frames Muslims, migrants and asylum seekers as agents of global terror, Burnt Shadows belongs to the latter category. Yet, by making Hiroko Tanaka-Ashraf the novel's interpreter of personal and collective losses, of stories of estrangement and reconnections, betrayal and atonement, Shamsie transcends the narrow confines of ethnicity and religion responsible for the worst excesses of the twentieth and early twenty-first centuries. Her plea for universalism is a far cry from the homogenisation of global culture.

\section{Pascal ZINCK \\ Université de Lille 3}

\section{Works Cited}

Ashcroft, Bill, Gareth Griffiths, and Helen Tiffin. The Empire Writes Back: Theory and Practice in Post-Colonial Literatures. London: Routledge 2002.

Avant, Deborah. The Market for Force: The Consequences of Privatizing Security. Cambridge: Cambridge UP, 2005.

Badiou, Alain. Ethics: An Essay on the Understanding of Evil, London: Verso, 2001.

—. "On Evil: An Interview with Alain Badiou." Cabinet 5 (Winter 2001/02). Available online <http://www.cabinetmagazine.org/issues/5/alainbadiou.php>

BARBER, Benjamin R. Jihad vs. McWorld: How Globalism and Tribalism are Reshaping the World. New York: Ballantine Books, 1996.

Сномsку, Noam. Hegemony or Survival. America's Quest for Global Dominance. New York: Metropolitan Books, 2003.

Forster, Edward Morgan. A Passage to India. 1924. Harmondsworth: Penguin, 1974.

Hamid, Mohsin. The Reluctant Fundamentalist. Harmondsworth: Penguin, 2007.

Hardt, Michael, and Toni Negri. Empire. Cambridge, MA: Harvard UP, 2001.

Husain, Intizar. Basti. New Delhi: Oxford UP, 2007.

Khan, Uzma Aslam. Trespassing. London: Picador, 2005.

Iвuse, Masuji. Ame Kuroi. Shinchōsha: Tokyo, 1970.

Ishiguro, Kazuo. A Pale View of Hills. London: Faber and Faber, 1982.

-. When We Were Orphans. London: Faber and Faber, 2000. 
Lechner, Frank J. and John Boli, eds. The Globalization Reader. Oxford: Blackwell Publishing, 2003.

Magris, Claudio. Microcosmi. Milan: Garzanti, 1997.

Мвемвe, Achille. "Necropolitics." Public Culture 15.1 (2003): 11-40.

Ondaatje, Michael. The English Patient. New Yok: Vintage Books, 1993.

Nelson, Emmanuel S., ed. Reworlding: The Literature of the Indian Diaspora. New York: Greenwood P, 1992.

PArry, Benita. Postcolonial Studies: A Materialist Critique. London: Routledge, 2004.

Robertson, Roland. "Glocalization: Time-space and Homogeneity-Heterogeneity." Global Modernities. Ed. M. Featherstone, S. Lash and R. Robertson. London: Sage Publications, 1995. 25-44.

Rushdie, Salman. “The Empire Writes Back with a Vengeance.” The Times, 3 July 1982, 8.

—. Imaginary Homelands: Essays and Criticsm, 1981-1991. Harmondsworth: Penguin, 1991.

—. Fury. London: Jonathan Cape, 2002.

-. Shalimar the Clown. New York: Vintage, 2005.

SAID, Edward. Culture and Imperialism. New York: Random House, 1993.

Shamsie, Kamila. Broken Verses. New York: Harcourt, 2005.

—. Burnt Shadows. London: Bloomsbury, 2009.

Singer, Peter W. Corporate Warriors: The Rise of the Privatized Military Industry. Ithaca, NY.: Cornell UP, 2003.

SpIvaK, Gayatri Chakravorty. "Can the Subaltern Speak?: Speculating on Widow Sacrifice.” Wedge 7/8 (Winter-Spring 1985): 120-130.

-. "Can the Subaltern Speak?" Colonial Discourse and Postcolonial Theory. New York, NY: Columbia UP, 1994. 66-111.

Tomlinson, John. Globalization and Culture. Chicago: U of Chicago P, 1999.

Wallerstein, Imanuel. "America and the World: The Twin Towers as Metaphor." Understanding September 11. Eds. Craig Calhoun et al. New York: New York P, 2001. 345-360. Available online http://www.iwallerstein.com/wp-content/uploads/docs/ America-and-the\%20World-The-Twin-Towers-as-Metaphor.pdf.

-. Decline of American Power: The U.S. in a Chaotic World. New York: New P, 2003.

- "Globalization or The Age of Transition? A Long-Term View of the Trajectory of the World-System,” Available online http://fbc.binghamton.edu/iwtrajws.htm. 